\title{
Carme Riera's En el último azul (1994): An encounter with Spain's conflicted past
}

\author{
Nicola Gilmour
}

Carme Riera's novel En el último azul-published first in Catalan in 1994 and then in 1996 in a Castilian translation prepared by the author herself-presents the story of a group of crypto-Jews (chuetas) living in seventeenth-century Majorca whose failed attempt to flee persecution leads to disaster. ${ }^{1}$ Published shortly after 1992 - the five-hundredth anniversary of, amongst other things, the official Edict of Expulsion of the Jews - this novel counters the multifaceted positive commemorative discourse of that year (in which Spain hosted a number of significant cultural events that celebrated 'Spain's coming of age as a modern, democratic European nation-state' $)^{2}$ with a representation intended to reveal some of 1492's darker consequences. ${ }^{3}$ The novel, awarded the Premio Nacional de Literatura in 1995 (the first novel in a language other than Castilian to receive it), is based on historical events that took place between 1687 and 1691, but, as the author suggests, in her retelling of them in the genre of the historical novel a significant degree of poetic licence has been exercised.

First and foremost, En el último azul is a moving, novelistic account of the life and death of a persecuted community. As Akiko Tsuchiya has observed, however, it is also 'a complex hybrid of history and fiction' ${ }^{4}$ It is a novel dominated by questions regarding the relationship between official history and individual and collective memory, by questions regarding the relationship between past and present, and by questions as to where fiction might fit within these debates. Indeed, much of the critical discussion of the novel has centred upon what En el

\footnotetext{
1 Riera, C. 1994, Dins el darrer Blau, Destino, Barcelona; and Riera, C. 1996, En el último azul, Alfaguara, Madrid.

2 Graham, H. and Sánchez, A. 1995, 'The politics of 1992', in H. Graham and J. Labanyi (eds), Spanish Cultural Studies. An introduction. The struggle for modernity, Oxford University Press, New York, pp. 406-18, at p. 406. The cultural events referred to include the Olympiad in Barcelona, the Expo 92 in Seville and Madrid being named the European City of Culture, as well as many of the official commemorations of the 'Descubrimiento'.

3 José Francisco Colmeiro, in his Memoria histórica e identidad cultural. De la postguerra a la postmodernidad (2005, Anthropos, Barcelona), emphasises the way in which these grand institutional commemorative events of 1992 glossed over or erased the memory of the negative consequences of 1492, which he lists as follows: 'las múltiples leyendas negras de la historia nacional: el expolio de las colonizaciones, el esclavismo, el racismo, el oscurantismo, el odio y la exclusión del otro, las tensiones internas desestabilizadoras' (p. 34).

4 Tsuchiya, A. 2001, 'Discourse and the strategies of power in Carme Riera's En el último azul: a cultural analysis of the Inquisition', Journal of Iberian and Latin American Studies (JILAS), vol. 7, no. 1, pp. 77-84, at p. 78 .
} 
último azul, as a work of fiction, adds to the historical account of those events. Furthermore, almost every critic who has written of this novel has linked it to some aspect of the present, either the context in which the novel was published or the critic's own present, for, as Carlos García Gual has argued, the historical novel alludes frequently to the present in its evocation of the past and 'atrae ese pasado evocado hacia el presente, mostrando la semejanza de uno y otro' . ${ }^{5}$ There can be no question that making reference to historical memory was extremely relevant at the time the novel was written and is even more so now in the current Spanish political climate, with the passing of the Law of Historical Memory in 2007 and the growing demand for recognition of the victims of the Civil War and the Franco regime.

Critics have viewed the text in very different ways: for Janet Pérez, En el último azul presents a kind of historiography in line with the concepts propounded by the New Historicists. ${ }^{6}$ Neus Carbonell argues, applying post-colonial theories of the subaltern, that it might be read as 'a narrative of resistance from the ethical perspective of the responsibility for the repressed ${ }^{\prime}{ }^{7}$ while Tsuchiya analyses it as an exposé, partaking equally of history and fiction, of the discursive mechanisms used by the Spanish Inquisition to produce a disciplinary society. ${ }^{8}$ For Geraldine Cleary Nichols, En el último azul embodies 'some of the "infinidades de historias" behind the capital-h Historical accounts of the last autos de fe [sic] resulting in loss of life in Majorca', and thus unsettles the official documents' monological presentation of the chuetas' last years, thus restoring 'some vestige of speech to the silenced'. ${ }^{9}$ Reyes Coll-Tellechea, on the other hand, has linked the novel to anxieties relating to the full entry of Spain into the European Union and the ethnic intolerance and genocide surrounding the break-up of the former Yugoslavia. ${ }^{10}$

In particular, the critics have found it irresistibly tempting to read the narrative in juxtaposition with the three-page 'Afterword/Nota' at the end of the novel where the author sets out some of her aims in the production of the text. Here Riera also lays out briefly what she understands to be the salient differences between fictional and historical narrative and positions her text in relation to

5 García Gual, C. 2002, Apología de la novela histórica y otros ensayos, Península, Barcelona, p. 139.

6 Pérez, J. 1999, 'Text and context of Carme Riera's En el último azul', Letras peninsulares, vol. 12, nos 2-3 (Fall), pp. 239-54.

7 Carbonell, N. 1999, 'The ethics of dissidence: resistance and relationality in Carme Riera's Dins el darrer blau', in K. M. Glenn, M. Servodidio and M. S. Vázquez (eds), Moveable Margins. The narrative art of Carme Riera, Bucknell University Press, Lewisberg, Pa, pp. 218-30, at p. 223.

8 Tsuchiya, 'Discourse and the strategies of power', p. 83.

9 Nichols, G. C. 1999, “Tras su hache mayúscula": Carme Riera and the exploration of history in Dins el darrer blau', in K. M. Glenn, M. Servodidio and M. S. Vázquez (eds), Moveable Margins. The narrative art of Carme Riera, Bucknell University Press, Lewisberg, Pa, pp. 200-17, at pp. 203, 208.

10 Coll-Tellechea, R. 2002, 'En el último azul by Carme Riera: memory's future and the history of the Spanish Jews', in J. B. McInnis (ed.), Models in Medieval Iberian Literature and their Modern Reflections: Convivencia as structural, cultural, and sexual ideal, Juan de la Cuesta, Newark, Delaware, pp. 307-14. 
these two poles. This article too will examine the novel in relation to this 'Nota'. Rather than address the dichotomy Riera establishes between history and fiction (which has been dealt with in detail by other critics), in this article, I wish to examine the final paragraph of the 'Nota' in which the author declares her novel to be an apology of sorts to the descendants of the chuetas, who, for more than 300 years, have suffered marginalisation and humiliation at the hands of their fellow Majorcans. In particular, this article will explore this assertion that a work of fiction could act as a historical apology and examine how that might function.

Before going on to discuss these issues, some brief summary of the key structural and thematic elements of the novel is necessary since they feed into the argument elaborated subsequently. What is more, I do not wish to ignore what is in fact an excellent 385-page novel in favour of the three-page afterword. En el último azul is structured in three parts: Part I, the longest, sets the scene for the escape. It depicts the way of life of the close-knit community of la Calle Sagell, a group of approximately 200 crypto-Jews and nuevos cristianos in Palma de Mallorca. It introduces the various characters and explains the group's growing need to flee due to the presence of a malsin (or informant) in their midst. Part II narrates the failure of the planned escape due to inclement weather, the subsequent arrest of the group as they try to return to their homes after curfew, and the politically motivated riots that follow. Part III depicts the interrogation and torture of the detainees, the trials, the politicking surrounding the trials, the attempts by exiled compatriots in Livorno to negotiate the release of the chuetas and, finally, the sentencing of the group and the execution of 37 of its members. The narration takes an ostensibly neutral third-person perspective, with multiple points of focalisation, allowing the reader into the minds of different characters, both those in positions of power (the Viceroy, the Chief Inquisitor, the priests, and so on) and those in positions of vulnerability - that is, those who suffer and eventually die, as well as those who attempt to save them and witness their deaths.

The novel begins like an episode from The Arabian Nights, as one critic has commented, ${ }^{11}$ with a minor character, João Peres, a Portuguese sailor, pursuing sexual adventure. He is on a quest to find a beautiful and mysterious woman described to him by another sailor, Captain Andreas Harts, Peres's actions driven by his memories of Harts' evocative and erotic storytelling. En el último azul ends with that same character, Peres, acquiring a rather more traumatic and shocking memory - the sight of Gabriel Valls being burnt to death at the stake - a memory he wishes he could blot out. In fact, all the characters in the

11 Nichols, “"Tras su hache mayúscula"”, p. 201. 
novel are haunted by memories of one type or another (of lost loves, of violence suffered or committed, of past humiliations). Indeed, memory is not only an important part of the characters' lives; it is also an integral theme of the novel.

Memory (specifically the chueta memories) provides a contrast with the official discourse from which Hispanic Judaism is 'disappeared' by the Edict of Expulsion in 1492. The very existence of the crypto-Jewish characters depends on memory: their collective and individual ability to remember (to a greater or lesser degree) their traditions and to pass them on to their children at a certain age. Their life as an underground community depends on the retention of those memories of their excluded religious and cultural tradition. Their memory also functions as an alternative history, a subtext contradicting the official state version of Spanish history, in which, of course, they no longer exist as Jews at all, only as Christians, and defective ones at that. Furthermore, as Nichols states, memory actually 'constitutes them as Jews' ${ }^{12}$ - a reference to the Zakhor, the religious mandate of Judaism to remember. Memory is partly what keeps these characters alive during their long stay in prison: 'En el rebujo de la memoria afloraban pequeños detalles que hasta entonces no habian sido tomados en cuenta, pero que ahora les servian como muletas de aquella vida coja y manca que padecian. ${ }^{13}$ For these characters, then, memory is not only key to their identity; it represents their support in times of great trial.

At the same time, memory is also integral to the persecution of these characters since the official memory also holds their former identity present: the Inquisition (and the Majorcan society that surrounds them) never forgets that the residents of La Calle were once Jews, regardless of whether or not they practise Christianity. Indeed, as is made clear in the 'Nota' and other critical articles, this memory has played a part in the cultural life of Majorca until the present day, having a negative impact on the descendants of the chuetas even at the end of the twentieth century. Thus, the theme of memory is woven subtly into the very structure of the novel, signalling the importance of remembering, both as an alternative or supplement to official history and as a process of bearing witness by which the traumatic events of the long-distant past, the consequences of that official history, can be kept alive. Memory is presented as the intimate human face of history, and giving it pre-eminence in her novel is an important part of Riera's technique to undermine the official discourse of Spanish history. By creating these imagined (fictional) memories, Riera makes visible the invisiblethe absence upon which present-day Majorca (and Spain) is constructed-and reveals the suffering of those long-dead chuetas. ${ }^{14}$

12 Ibid., pp. 211-12.

13 Riera, En el último azul, p. 353.

14 For more on the need to recover historical memory, see Mate, R. 2008, La herencia del olvido. Ensayos en torno a la razón compasiva, Errata naturae, Madrid, in particular the chapter entitled 'Tierra y huesos. Reflexiones sobre la historia, la memoria y la "memoria histórica"'. 
In making the victims of the past visible, Riera needs to make them human, and one of the novel's greatest strengths is the depth of characterisation, the texture of the individuals who come to life off the page - Jewish and Catholic, inquisitor and victim, good and evil, fictional and historical, all are rounded and complexly human. Gabriel Valls, the leader of the would-be escapees, for example, remembers both the terror of being persecuted as a child for his Jewish origin and, equally, the shame and guilt of remembering the way in which he took his revenge against a former friend turned persecutor (a boy of Moorish origin) by sodomising him with a stick. ${ }^{15}$ The chief inquisitor is cold and implacable in his efforts to exterminate heresy, but he is also shown to be a devoted son who makes superhuman efforts to get to his mother's deathbed, and the reader witnesses his despair when he fails. ${ }^{16}$ Even Costura, the malsin, is no cardboard cut-out villain. His betrayal of his relatives is motivated by a complex blend of genuine religious belief, greed, loneliness after the death of his much-loved Christian wife, and a sense of abandonment by his community. No one character in the novel is entirely good or entirely evil and, as such, the novel undermines 'fantasies of unified identity... [thus] unsettling positions of comfortable certainty in the addressees' identity' ${ }^{17}$ Indeed, to a certain extent, good and evil become destabilised categories, as do history and fiction, as the novel depicts what Graves and Rechiniewski describe as the 'shades of grey' that 'inevitably characterise the actions of those caught up in situations of oppression of one group by another' ${ }^{18}$ The novel shows the reader that in fact the crypto-Jews of Majorca were people, members of Majorcan society, not the Christ-killing outsiders they were made out to be, people who were caught up in larger forces, just like everyone else-including the inquisitors. And so, we can put ourselves in their place and feel empathy for them, entering into what Carbonell calls 'an ethics of relationality with the Other' ${ }^{19}$

Ultimately, however, there are winners (who kill) and losers (who are killed), and falling into one category or the other is, Riera's novel suggests, due largely to the political and institutional forces at work, manipulating the situation. In the final analysis, Riera lays the broader responsibility for the destruction of the chueta community and the ongoing humiliation of their descendants at the feet of the Church and Majorcan, and by extension Spanish, society. Those larger forces, in conjunction with bad luck, as well as individual acts of cruelty, within an environment that sanctioned the exclusion and marginalisation of the chueta community, are shown to be what destroyed the chuetas, rather than any

15 Riera, En el último azul, pp. 83-6.

16 Ibid., pp. 146-57.

17 Carbonell, 'The ethics of dissidence', p. 229.

18 Graves, M. and Rechiniewski, E. 2010, 'From collective memory to transcultural remembrance', PORTAL Journal of Multidisciplinary International Studies, vol. 7, no. 1 (May), p. 11, viewed 4 August 2010, <http:// epress.lib.uts.edu.au/ojs/index.php/portal/article/view/1534/1651>

19 Carbonell, 'The ethics of dissidence', p. 229. 
heresy or wrongdoing on their part. It might seem, then, that Riera is somehow saying that no-one is responsible and that it was 'just one of those things that happened that cannot be changed or remedied now'. In the last paragraph of the 'Nota', however, she specifically links the past depicted in the novel to an ongoing suffering in the present for which she does assign responsibility.

Ostensibly, the 'Nota' sets out the way in which Riera approached the weaving together of historical fact and literary imagination. It begins with a brief summary of the historical events on which the novel is based, and then the author goes on to specify in some detail the ways in which what she has written differs from the 'historical events'. She has changed the flow of time, lengthening the time at the beginning, 'para que el lector pudiera entrar de manera gradual en el conflicto', and shortening it towards the end, 'para hacerla más compacta e intensa' 20 - that is, she adjusts events for dramatic impact. She also points out that the character of Peres who opens and closes the novel is fictional and that Blanca María Pires (the mysterious lady of Harts' story) is a character drawn from literature. ${ }^{21}$ The Viceroy is not 'real', nor is his nephew or the critics' favourite character, the prostitute, Beatriu Mas. ${ }^{22}$

Riera then links the characters who are based on real people to their historical counterparts, stating that she changed their names to signal that her book is fiction: 'He cambiado nombres, apellidos y apodos aposta, para señalar así que mi libro no es historia sino ficción.' ${ }^{23}$ She goes on to state that this is integral to her idea of the fundamental difference between history and fiction: 'En los dominios de la historia ningún material debe ser manipulado; en el de la novela, por muy histórica que sea, mientras se mantenga la verosimilitud, la verdad de cohesión, todo es válido y, en consecuencia, legítimo. ${ }^{24}$ History must be above manipulation, and strictly factual, she asserts, while literature can do what it likes, as long as it looks and feels real. Many critics have picked up on this definition (which seems to free literature from any kind of obligation to historical 'truth'), as it is clearly somewhat problematic. As Tsuchiya states: "The "historicity" or "fictionality" of literary discourses...cannot be based simply on the question of referential authority or truth value ascribable (or not ascribable) to the textual referent. ${ }^{25}$

Having thus disavowed her novel's link to 'real events', Riera then rather paradoxically proceeds to reference the archival research she has carried out and the experts she has consulted to ensure her text's authenticity, as well as

\footnotetext{
20 Riera, En el último azul, pp. 387, 386.

21 Ibid., p. 387.

22 Ibid., p. 387.

23 Ibid., p. 387.

24 Ibid., p. 387.

25 Tsuchiya, 'Discourse and the strategies of power', p. 77. Furthermore, Riera's formulation presents a somewhat simplified concept of the nature of historical research; however, to discuss this in detail is beyond the scope of this article.
} 
her not inconsiderable efforts to get the language right, to ensure that it is not anachronistic. ${ }^{26}$ Here, then, Riera appears to be wanting to have it both ways, much as James E. Young has observed in relation to Holocaust documentary fiction: by mixing actual events and fictional characters, the writer both invokes poetic licence (therefore eschewing the demand for total historical accuracy) and imbues his or her fiction with authenticity. ${ }^{27}$ Young calls this insistence on a narrative's factuality the 'rhetoric of fact' and argues that if used merely to move the reader then it serves only to wring 'pleasure from the naked pain of the victims'.$^{28}$ But, he continues, if an author refrains from 'conferring an essential fictionality on actual historical events then we might take into account both the legitimate impulse to document events and the manner in which "real past events" are inevitably fictionalized by any narrative that gives them form' ${ }^{29}$ That is, Riera's insistence on fictionality and authenticity might serve to make readers doubt the absolute veracity of official historical discourse in regard to the events being described, and to point to the absence of key aspects of the traumatic experiences of the past from the official Inquisitorial historical record. ${ }^{30}$

Riera's novel weaves together imagined memories (fiction) to supplement the official history, giving a voice to the marginalised and thus providing their alternative version of events, as indeed happens in many historical novels. Indeed, she goes further to discredit the makers of the official history (represented by the legajos of the Inquisition, and a work called La fe triunfante, an 'intemperate' and 'vitriolic' eyewitness account written at the time by Jesuit priest Francisco Garau, represented by Padre Amengual in the novel). ${ }^{31}$ In her depiction of the trials, Riera unmasks the Inquisition's less than holy motives - greed, revenge, fanaticism and ambition-contradicting the historical record, and supplying the truth behind history. In fact, in a sense, the novel puts the Inquisition itself on trial before the jury of its readers. ${ }^{32}$ In this way, En el último azul seems to bear out Juan Cruz Mendizábal's suggestion that a 'country's novels may supply a truer account of its culture than its histories, which report facts selected to support the ruling ethos'.$^{33}$

\footnotetext{
26 Riera, En el último azul, p. 388.

27 Young, J. E. 1988, Writing and Rewriting the Holocaust: Narrative and the consequences of interpretation, Indiana University Press, Bloomington, p. 53.

28 Ibid., p. 62.

29 Ibid., p. 63.

30 Nichols, "“Tras su hache mayúscula"', p. 204.

31 Ibid., p. 205.

32 I am indebted to Professor Christine Arkinstall of the University of Auckland for this very pertinent insight.

33 Juan Cruz Mendizabal, quoted in Judy B. McInnis's introduction to her edited book, Models in Medieval Iberian Literature and their Modern Reflections: Convivencia as structural, cultural, and sexual ideal (2002, Juan de la Cuesta, Newark, Delaware), pp. xlix-l.
} 
By providing an imagined insight into the actions and memories of historical and fictional characters, En el último azul presents the kind of ephemeral personal detail that the historical record would usually efface. Thus, in a sense, the novel returns the individuality and humanity to those involved, as Aharon Appelfeld urges writers to do in the context of Holocaust literature, in order 'to rescue the suffering...from dreadful anonymity, and to restore the person's given and family name, to give the tortured person back his human form' ${ }^{34}$

Riera specifically mentions such an intention in her 'Nota' as being one of those that lies behind the novel. She states that she wanted to present a picture of the chuetas' way of life that would allow the reader to understand them, to understand 'cómo fueron sus casas, sus costumbres, qué oficios tenían, y cómo algunos de ellos mantenian alianzas con los nobles en el negocio del mar'. ${ }^{35}$ Understanding the characters' daily reality reveals their normal 'human-ness' and, presumably, encourages an empathetic reaction towards their suffering on the part of the reader.

Further intentions are set out in the final paragraph of the 'Nota', where Riera, in an ambiguous move, denies any intention of polemic but at the same time makes what could be viewed as a controversial ethical claim:

En el último azul no tiene, aunque pueda parecerlo, ninguna intención polémica. No pretende hurgar en viejas heridas ni abrir tampoco otras nuevas, haciendo referencia a la intolerancia de buena parte de la sociedad mallorquina contra un grupo de mallorquines de procedencia judia, ya que quizá aún peores que los hechos de 1691 fueron sus trágicas consecuencias, que marginaron y humillaron durante siglos hasta hoy mismo a los descendientes de aquellos mártires judios quemados en los autos de fe. A todos ellos, me parece que los mallorquines de buena voluntad debemos pedir perdón. Ésa es también una de las intenciones de la novela. ${ }^{36}$

Here we seem to have travelled a long way from the view that 'it is only fiction', into the realm of the novel as an ethical response to history. Despite the disclaimer regarding stirring up controversy or 'reopening old wounds' (that famous accusation usually thrown by the political right to discourage reconsideration of the past), and despite her stated lack of desire to create new wounds, in what follows Riera uncovers a wound that is very much unhealed and largely hidden from sight: the humiliation suffered over the centuries by the descendants of this group of Majorcans. So grievous is this wound that the author argues that these victims are owed an apology by the Majorcan community and furthermore suggests (although the sentence itself is rather vague) that this novel is designed

34 Appelfeld, A. 1988, 'After the Holocaust', in B. Lang (ed.), Writing and the Holocaust, pp. 83-92, at p. 92.

35 Riera, En el último azul, pp. 387-8.

36 Ibid., pp. 388-9. 
to embody that apology. Thus, not only is the novel designed to represent an episode of Spanish history, to supplement it by inserting the voices of history's victims, or contradict it, according to Riera in the 'Nota', En el último azul is also intended to compensate for it, to apologise for historical wrongs committed.

It is this bold claim of a fictional work to the status of a 'retrospective apology'37 that I would now like to explore because, at first glance, the idea of a fictional apology seems rather like a cheque drawn on a bank account with insufficient funds to honour it. ${ }^{38}$ To this end, I would like to pose the following questions: if a traumatic historical event has been perpetrated by one community upon another and is inadequately publicly recognised or distorted in official documents and largely ignored by the modern community, what role can literature play in righting that wrong? For Weyeneth, retrospective apologies 'run the gamut from the obvious (words of regret delivered at a podium) to the imaginative (a multi-year walk of reconciliation)', but can something as imaginative as a historical novel function as an apology? Or is there perhaps something inherently contradictory about such an assertion? ${ }^{39}$ And is this novel functioning in that capacity?

Given that, as Coll-Tellechea states, 'fictional stories about Spain's historical past reach many more readers than the history books', ${ }^{40}$ fiction can certainly serve as a way of raising a nation's consciousness about the past. It can act as an effective testimonial of sorts by bringing a version of the 'facts' of the situation to wider public scrutiny, or by maintaining the visibility of certain traumatic events of the past, thus potentially reaching a wider audience to be shocked and moved to demand historical justice. Indeed, as Jorge Semprún has affirmed, fiction might give a sense of witnessing those distant events even though all the witnesses are long dead. He argues that fiction will increasingly become an integral channel for the recuperation of historical memory: 'Es preciso recuperar la memoria histórica a través de la ficción, porque pronto no quedarán testigos de lo sucedido.' ${ }^{41}$

But the recovery of lost 'memories' is not an apology; it can really only be a precursor to apology. A historical novel can remind us that, although an injustice might have taken place several hundred years ago, there are often

\footnotetext{
37 The term is one used by Robert Weyeneth in 'The power of apology and the process of historical reconciliation' (The Public Historian, vol. 23, no. 3 [Summer 2001], pp. 9-38). He defines it as an acknowledgment of 'injustices of a systematic or structural nature (such as anti-Semitism and colonialism) or long-past historical events (like the Crusades, the Inquisition and the slave trade)' (p. 35).

38 This provocative metaphor was suggested to me by Professor Alfredo Martínez Expósito at the conference where an earlier version of this article was presented.

39 Weyeneth, 'The power of apology and the process of historical reconciliation', p. 12

40 Coll-Tellechea, 'En el último azul by Carme Riera', p. 307.

41 Quoted in Ferrán, O. 2007, Working Through Memory. Writing and remembrance in contemporary Spanish narrative, Bucknell University Press, Lewisburg, Pa, p. 277.
} 
ongoing implications for the present, as in the case of the descendants of the chuetas. It can remind us that the past cannot really be dead when certain human characteristics (intolerance, fanaticism, hatred, greed, and so on) rear their ugly heads, generation after generation. Riera herself has stated that the only solution to what she calls '[l]as hogueras del fanatismo y la ortodoxia [que] son una constante del siglo XXI' is to 'matar el yo racista que llevamos dentro y eso sólo se puede conseguir colocándonos en el lugar del otro, sintiéndote agredida' — that is, to put oneself in the position of the other, via exercising empathy, perhaps through the act of reading, or even writing, a novel..$^{42}$

For Leslie Epstein, writer of novels about the Holocaust, the role of the novelist when working with traumatic events of the past is 'to create a bond... between the reader and every aspect of the world that has been salvaged through imagination', and he affirms that such a 'sense of responsibility and connectedness can be achieved only by the creative artist - and by creative readers as well' ${ }^{43}$ A work of fiction, then, can bring individual life to the victims of traumatic historical events, revealing their humanity in a way that might bring them closer to the readers, thus stimulating an empathetic reaction, creating precisely that bond or connectedness and that sense of responsibility. In respect to longago events, when all the eyewitnesses are long dead, fiction provides perhaps our only access to the kind of details that history has effaced - the feelings and emotional realities of everyday life. ${ }^{44}$

Fiction can fulfil all of these functions - and many of them overlap with certain aspects of a retrospective apology. For Weyeneth, the retrospective apology takes the long view and 'acknowledges that history matters: perpetrators and immediate victims may be gone, but their legacy continues to shape the present ${ }^{\prime}{ }^{45}$ He notes that 'history casts long shadows, whether the present wants it to or not, and the general retrospective apology seeks to reckon with the shades' ${ }^{46}$ Recognition of just this kind of impact of the past on the present is very clear in Riera's 'Nota'. Additionally, like the historical novel, the retrospective apology 'provides a means for the present generation to respond to the past and to draw lessons from it' ${ }^{47}$ Clearly, then, there are significant points of contact between a historical novel of the type Riera has written and the concept of the retrospective apology, but the question remains, can a novel constitute an apology?

\footnotetext{
42 Quoted in Carbonell, 'The ethics of dissidence', p. 224.

43 Epstein, L. 1988, 'Writing about the Holocaust', in B. Lang (ed.), Writing and the Holocaust, Holmes and Meier, New York and London, pp. 261-76, at p. 269.

44 This is of course a fantasy - the author's and the readers' fantasy about what those characters' feelings and emotional realities might have been; nevertheless, it has a powerful impact. For more on the idea of fantasy and witnessing in relation to the Holocaust, see Weiss, G. 2004, Fantasies of Witnessing. Postwar efforts to experience the Holocaust, Cornell University Press, Ithaca, NY, and London.

45 Weyeneth, 'The power of apology and the process of historical reconciliation', p. 35.

46 Ibid., p. 35.

47 Ibid., p. 36.
} 
In Mea Culpa: A sociology of apology and reconciliation, Nicholas Tavuchis examines the nature of the apology as a speech act and asks what is required for an apology to be successful. For him, an apology is a dyadic interaction whose 'exclusive, ultimate, and ineluctable focus is upon interaction between the primordial social categories of Offender and Offended' ${ }^{48}$ He goes on to set out three stages required for a speech act to qualify as an apology: first, the naming of the offence and the identification of it as an apologisable action responsive to a call for an apology ('if there is no call, no urgency to remember, no struggle against the natural tendency to forget, then there is no occasion for apology'). ${ }^{49}$ Then, there is the apology itself with its admission of wrongdoing and expression of sorrow and regret. Finally, there is the response of the injured party, who might or might not accept the apology and forgive the offence. ${ }^{50}$ Tavuchis delineates the structure of possible apologies as being interpersonal (that is, one to one), or between individuals and collectivities (one to many or many to one) and between collectivities (many to many). This last formulation covers situations where the state speaks on behalf of the collectivity, and indeed, in recent times, most apologies for historical injustices have been made by states, symbolically representing the community of a nation. In the light of this, it seems that the kind of apology Riera is referring to in this novel hovers ambiguously somewhere between the one-to-many and the many-to-many varieties of apologies. Given that Riera is an individual and not an officially accredited person to whom the Offender (or perpetrator) group or their descendants has delegated such a task then what she is doing in the novel cannot constitute a successful apology. For, as Tavuchis argues, 'an apology proffered without proper credentials, that is, lacking the moral imprimatur of the group, amounts to no apology at all. It means nothing because it represents the unaccredited One and not the Mandate of the Many. ${ }^{51}$ One might possibly argue that, by virtue of her profession as a writer and public intellectual - thus perhaps having an obligation to act as the conscience of society-Riera is accredited in some way. This is, however, somewhat of a long bow to draw.

It seems that what Riera is doing here is 'calling for an apology'; she is laying out the details of the offence committed and is doing it (presumably) from within the collectivity of the Offenders. ${ }^{52}$ She has observed in the history of Majorca a

48 Tavuchis, N. 1991, Mea Culpa: A sociology of apology and reconciliation, Stanford University Press, Stanford, Calif., p. 46.

49 Ibid., p. 22.

50 As the concept of apologies for historical injustices has developed in practice since 1991 (the date of Tavuchis's book), these last two stages have often become conflated. For example, in New Zealand, in the context of the settling of historical injustices committed by the Crown against the indigenous Maori, the Crown negotiates the form and wording of apologies with the tribes involved. This kind of negotiation is not normally found in interpersonal one-to-one apologies.

51 Tavuchis, Mea Culpa, p. 101.

52 Apparently, there has been little demand for an apology from the Offended. In fact, Nichols, in her essay, refers to an account in the Majorcan press in which five people of chueta descent argued against a proposed 
situation that offends her sense of how that group of which she forms a partMajorcan society - should behave, a situation that caused persecution, death and suffering to a subset of that community. Furthermore, and perhaps crucially for its relevance to the present, that historical wrong has had an ongoing impact that requires redress, an apology. While the responsibility for the wrongdoing in the past might lie at the feet of those institutions and people of the past, that of the ongoing discrimination and suffering, her 'Nota' seems to be implying, can be laid at the door of contemporary Majorcans as a group. In this kind of circumstance of state historical wrongdoing and collective discrimination the only meaningful mode of apology available, however, is that of many to many - a public apology from the state or the leaders of the Majorcan community or the Church - and Riera is not in the position to proffer that.

What she can do in her novel, and what I believe she is doing, is to stimulate, through her empathetic treatment of characters, the collective memory of those events that, it seems, is being expunged from the official record and fading from the collective memory. She implicitly understands that unless the collective memory of the offence is revived then there can be no redress and no healing or reconciliation, for a fading memory does not mean that the 'wound' or trauma will be healed. And, as Reyes Mate observes, an unresolved offence 'quedará ahi, oculta o latente, a la espera de que haya una conciencia moral sensible que la despierte. Esa huella estaría ahi, acompañando a la historia, porque la historia se ha construido sobre ella. ${ }^{.53}$ In Riera, we have that 'conciencia moral sensible', signalling the site of an unhealed wound with her novel. As Shoshana Felman has affirmed, '[a]rt is what makes silence speak', ${ }^{44}$ and Riera's retelling of the story of the chuetas from a subaltern perspective fills that silence, revealing truths or imagined stories that have not been told before-portraying, for example, the venal nature of the Majorcan Inquisition, ${ }^{55}$ or constructing an empathetic representation of what it might have been like to be persecuted in this way.

The reader is shocked into a realisation of how wrong the past actions were, but, to reiterate, this is an outline of the offence for which the apology is needed, rather than an apology per se. In a sense, however, this is a function that bears similarities to that of the collective apology, for as Tavuchis states, 'the major structural requirement and ultimate task of collective apologetic speech is to put things on record, to document as a prelude to reconciliation', which is arguably

\footnotetext{
statue commemorating the chuetas. They did so on the grounds that it would only revive the contempt formerly heaped upon them by Majorcan society 'just now when everything was practically forgotten' (Nichols, "“Tras su hache mayúscula"', n. 16, p. 217). This seems to indicate that some of this group of Offended, at least, want forgetting rather than remembering. And, to the best of my knowledge, the monument has still not been built. 53 Mate, La herencia del olvido, p. 160.

54 Felman, S. 2002, The Juridical Unconscious. Trials and traumas in the twentieth century, Harvard University Press, Cambridge, Mass., and London, p. 154.

55 Pérez, 'Text and context of Carme Riera's En el último azul', p. 241.
} 
what Riera is seeking to do in her novel. ${ }^{56}$ Yet, it is here that the status of Riera's text as a historical novel works against it being able to constitute this kind of apology or to function as historical documentation since fiction is not, and cannot be, equivalent to the historical record. It is in this context that one needs to read Riera's assertions to historical accuracy and authenticity, as she treads that tightrope between the historical offence and the imagining of how that offence might have felt to its victims and how it might have figured in their memories. She uses Young's 'rhetoric of fact' to give her fictional re-creation of collective memory some of the weight of history. It is her able deployment of the resources of fiction that enhances the power of her call for an apology (by, for example, enhancing reader empathy with the characters), but the use of these very same resources militates against this novel being able to proffer the apology that she says is one of her purposes.

Thus, a novel - in this instance, En el último azul-can provide a 'mode of articulation' for collective memory. ${ }^{57}$ It can create or contribute to a groundswell of public opinion that might, if strong enough, lead to an official, collective apology on behalf of a remorseful community in general or on behalf of the political or institutional entity representing the Offenders. I would argue, however, that for an apology for historical injustice to be meaningful, it cannot be delivered in a novel, for the reasons outlined above. And this novel, despite the words of the author in the 'Nota', does not act as an apology, but rather as a call for an apology from within the Offender group by attempting to resuscitate the collective memory of that trauma - hence the insistent emphasis on memory in the novel.

Riera is right in asserting that an offence has been committed, both in the seventeenth century and continuing now, and that an apology might be owed. To my knowledge, one has not been offered and perhaps one is not likely to be outside the pages of this novel, especially given the lapse in time since the original events took place. Perhaps the fact that she is presenting this call in a novel might be more of an unarticulated acknowledgment of the fact that an official apology is unlikely to be made in the current climate of indifference. Felman writes that 'writers often feel compelled to testify through literary or artistic channels precisely when they know, or feel intuitively, that in the court of history...evidence will fail or will fall short' ${ }^{58}$ For Felman, literature is a 'precocious mode of bearing witness and of accessing reality when all other modes of knowledge are precluded or are rendered ineffectual' ${ }^{59}$

56 Tavuchis, Mea Culpa, p. 109.

57 Graves and Rechiniewski, ‘From collective memory to transcultural remembrance', p. 7.

58 Felman, The Juridical Unconscious, p. 96.

59 Ibid., p. 97. 
In conclusion, then, I would assert that this novel, and indeed literature or art in general, might play a valuable role in the process of reconciliation in the case of historical grievances by deploying its resources to raise community consciousness of the wrongs of the past. Without such awareness there is no possibility of getting an apology from the state or the Church or any other institution from whom it is owed. Riera's novel cannot constitute an apology but it can, through its empathetic representation of the victims of history, function as a call for an apology, which might ultimately, in the right circumstances, heal the wound that Riera has uncovered. 